\title{
Milking management practices and IMI in Jersey crossbred cows in changing scenario
}

\author{
CHAMPAK BHAKAT ${ }^{1}$, A CHATTERJEE ${ }^{2}$, D K MANDAL ${ }^{3}$, M KARUNAKARAN $^{4}$, \\ A MANDAL ${ }^{5}, \mathrm{~S} \mathrm{GARAI}^{6}$ and T K DUTTA ${ }^{7}$
}

ICAR-NDRI, ERS, Kalyani, West Bengal 741235 India

Received: 5 August 2016; Accepted: 19 September 2016

\begin{abstract}
Experiment was conducted on Jersey crossbred cows (12) to compare 2 management practices viz. hand and machine milking. Field investigations were also carried out on other milking management practices, IMI, hygiene status and cleanliness in 3 stages. A total of 459 milk samples were analysed. Farm experimentation revealed that SCC and MCMT were significantly higher in hand milking as compared to machine milking management. But milk yield and milk extraction rate were significantly lower in hand milking as compared to machine milking management. The time required for milking/animal was significantly higher in hand milking as compared to machine milking management. The morning and evening milk samples of both hand and machine milking showed higher values of SCC, MCMT, pH during evening as compared to morning session but milk yield and milk extraction rate were lower during evening as compared to morning session whereas time required for milking/animal was higher in morning as compared to evening time. Almost similar trend of fat and SNF (\%) were estimated in both milking session. Field investigation indicated that SCC, MCMT, pH were higher in IMI animal as compared to no-IMI animal whereas fat and SNF were lower in IMI animal as compared to no IMI animal. Teat dipping and screening of udders for mastitis were never followed by any farmer. Most of farmer having single cow, maintained good hygiene status and cleanliness but most of the farmer having $>3$ cows, maintained poor hygiene status. Farm experimentation concluded that the IMI can be reduced in machine milking practices in comparison to hand milking practices with higher milk quantity without affecting milk composition in Jersey crossbred cows. Field investigation concluded that there is a significant association between animal keeping pattern and hygiene status/cleanliness at study area. So efforts should be made to increase cleanliness and hygiene status in milking cows itself, housing of animal and milkers of farmer's house to reduce incidence of IMI in changing scenario.
\end{abstract}

Key words: Cleanliness, Farmer, Hygiene, Hand and machine milking, Milk characteristics

Milk production have not received adequate attention at lower Gangetic region and this has been a major obstacle in dairy development and export potential of milk and milk products. Dairy sector in this region needs urgent improvement in milk production by applying effective management practices. Also, the vital aspect of clean milk production and udder health still remains a major concern in changing scenario. Out of the total milk produced, cow milk represents approximately $83 \%$ of total milk production (Srivastava and Khetra 2016). The milk characteristics in terms of milk composition, yield, somatic cell count (SCC)

Present Address: ${ }^{1}$ Principal Scientist and I/C (bhakat56 @ gmail.com), ${ }^{3}$ Principal Scientist (dkmandal1998@gmail.com), LPM Section. ${ }^{2}$ Principal Scientist (anuchatterjee@gamil.com), AN section. ${ }^{4}$ Senior Scientist (drmkarunakaran@gmail.com), Physiology section. ${ }^{5}$ Principal Scientist (ajoymandal @ rediffmail.com), AB section. ${ }^{6}$ Scientist (sanchita.bcka @ gmail.com), Extension section, NDRI, Karnal. ${ }^{7}$ Principal Scientist and Head (tkdcirg@gmail.com). and quality are important factors for dairy farmer, industry and consumer. The intramammary infections (IMI) are serious problems of crossbred dairy animals causing great economic losses due to reduction in milk yield and its value. However, as IMI are usually followed by an influx of leucocytes into milk, an increase in its SCC has been used widely as mastitis indicator (Hanan et al. 2015). SCC is a useful predictor of IMI and, therefore, an important component of milk in assessment aspects of quality, hygiene and mastitis control (Patil et al. 2015). The information on relationship of different milking management practices with IMI, SCC, milk characteristics, hygiene status, cleanliness under farm and field condition at lower Gangetic region are scanty. So, present study was conducted to improve commercial production of clean milk and udder health status in changing dairy scenario.

\section{MATERIALS AND METHODS}

The experiment was carried out in ERS-NDRI, Kalyani farm at lower Gangetic region of WB. Jersey crossbred (J 
$\times \mathrm{RS}$ ) cows (12) in mid-lactation and parities of 2 to 4 were selected from the institute's herd. Animals were divided into two comparable groups. The first group was milked by using full hand where as second group was milked by milking machine. After an adaptation time, the main experimental course was started and continued for 5 months. Almost similar type of other management like feeding, housing and health were provided to both experimental groups. A total of 459 milk samples were collected. Out of which 240 milk samples were collected from farm experimentation and 219 milk samples were collected from farmer's field. About $70 \mathrm{ml}$ of sample was collected from whole milk bucket after complete milking of animals in sterilized glass bottles at fortnightly interval from farm experimentation and at monthly interval from field. Milking time, milk yield and milk extraction rate were recorded in the morning and the afternoon milking sessions. The IMI were determined by SCC in milk sample, $\mathrm{pH}$ of milk and modified California mastitis test (MCMT). The SCC, fat, $\mathrm{SNF}, \mathrm{pH}$ and MCMT were determined in morning and evening milk samples.

Intramammary infection was detected by somatic cell count of milk samples which were carried out by an automatic machine. For cross checking of SCC, the manual procedure was also adapted by using microscopic method of somatic cell count. Before making the smear, the test milk samples were thoroughly mixed by gently shaking the vials and then $10 \mu \mathrm{l}(0.01 \mathrm{ml})$ of milk was taken on the pre drawn one square $\mathrm{cm}$ marked area over a grease free clean glass slide which was uniformly smeared with a standard sterilized bacteriological platinum loop and then the smears were air dried. The slides were also labeled for respective animal. The dried milk smears were stained with modified Newman's Lampert stain and examined under the oil immersion lens $(100 \times)$ of the microscope. Thirty different fields per smear were observed and average number of cells per field was then multiplied by the microscopic factor to obtain the number of cells per ml of milk. The $\mathrm{pH}$ of milk samples was determined by an electronically operated digital $\mathrm{pH}$ meter with glass electrode. The MCMT test was conducted as per procedure described by Devi (1997). The MCMT test is based on the principle of increase in number of leukocytes and alkalinity of the IMI milk. Estimation of fat percentage in milk was performed by adapting the Gerbers Butyrometric method. Milk SNF percentage was estimated by lactometer method using the ISI formula. Lactometer reading was taken through the ISI calibrated lactometer at $27^{\circ} \mathrm{C}$. The time required for milking and milk extraction rate was observed 5 days in a week. The logarithms of SCC number was used for normalizing data distribution. The data were analysed by using paired sample t-test (Snedecor and Cochran 1994).

One paged questionnaire was developed and tested for it's suitability of data collection. Information regarding management practices, cleaning and hygiene status followed in changing scenario of village conditions by the farmers were determined by means of a questionnaire.
Under different socio-economic conditions, the questionnaires were filled after interviewing farmer and then by personally recording the management conditions practiced under each household. Data were collected from 31 farmers having total of 73 milking animal by door to door visits from two adapted village (Muratipur and Chandamari of Nadia district of lower Gangetic region of WB). Repeated visits were made to follow up each and every animals and rapport was also build with dairy farmers. The quantitative and qualitative data were collected through interaction and discussion with farmers, key informants, housewives and secondary sources. To meet objectives of the study, both primary and secondary observations were recorded meticulously. Collected data were classified under different categories for interpretation. Milk samples and data were collected at monthly intervals. The SCC, fat, SNF, $\mathrm{pH}$ and MCMT were determined for each milk samples of farmer's field animals. The Chi-square test (Snedecor and Cochran 1994) was applied. The knowledge level of respondents regarding milking management was also assessed through knowledge index (Bhaskaran and Praveena 1982).

\section{RESULTS AND DISCUSSION}

Hand and machine milking management practices: The analysis of data of farm experimentation on IMI and milk characteristics in different milking management practices reveals that $\log _{10} \mathrm{SCC}$ (cells $/ \mathrm{ml}$ ) was significantly $(\mathrm{P}<0.01)$ higher in hand milking practice as compared to machine milking practice (Table 1). The range of Log SCC (cells/ $\mathrm{ml}$ ) greatly varied in both type of managements. The MCMT was found to be significantly $(\mathrm{P}<0.01)$ higher in group-I as compared to group-II. The $\mathrm{pH}$ of milk samples from both management practices varied non-significantly with slightly higher $\mathrm{pH}$ in hand milking as compared to machine milking practice. Although $\mathrm{pH}$ varied in normal range in all milk samples. The milk yield (kg/animal/milking) was significantly $(\mathrm{P}<0.01)$ higher in machine milking practice as compared to hand milking practice. The time required for milking (minute/animal/milking) was found to be lower in group-II as compared to group-I. The milk extraction rate $(\mathrm{kg} / \mathrm{minute})$ was significantly $(\mathrm{P}<0.01)$ higher in machine milking practice as compared to hand milking practice. The fat $(\%)$ was slightly higher in group-II as compared to group-I with a non-significant variation. The SNF (\%) varied non-significantly between two groups with slightly higher value in hand milking practice.

All the developed countries are using milk somatic cell counts (SCC) as a marker to determine the IMI/mammary health and quality of milk (Dang et al. 2007). Bhakat et al. (2016a) found that SCC $\left(\times 10^{5}\right.$ cells $\left./ \mathrm{ml}\right)$ was higher in SCM (Sub Clinical Mastitis) animals as compared to non-SCM animals. The SCC method is also less expensive than microbiological culture (Schukken et al. 2003). Seeing the importance of milk SCC internationally, SCC is conducted in Jersey crossbred cows in farm and field. Somatic cells of milk are white blood cells and epithelial cells, which 
Table 1. Comparative study of IMI and milk characteristics in different milking management practices

\begin{tabular}{lccc}
\hline Parameter & Sig & $\begin{array}{c}\text { Hand milking } \\
\text { (Group-I) }\end{array}$ & $\begin{array}{c}\text { Machine milking } \\
\text { (Group-II) }\end{array}$ \\
\hline $\log _{10} \mathrm{SCC}(\mathrm{cells} / \mathrm{ml})$ & $* *$ & $6.02 \pm 0.05$ & $4.87 \pm 0.04$ \\
$\mathrm{SCC} \times 10^{5}(\mathrm{cells} / \mathrm{ml})$ & & $7.73 \pm 0.24$ & $1.68 \pm 0.22$ \\
Range of Log SCC (cells/ml) & & 4.19 to 6.56 & 3.90 to 5.57 \\
MCMT & $* *$ & $3.06 \pm 0.09$ & $1.35 \pm 0.06$ \\
$\mathrm{pH}$ & $\mathrm{NS}$ & $6.65 \pm 0.02$ & $6.62 \pm 0.01$ \\
Milk yield (kg/animal/milking) & $* *$ & $4.38 \pm 0.22$ & $5.60 \pm 0.25$ \\
Time/animal/milking (min) & $* *$ & $10.08 \pm 0.30$ & $5.65 \pm 0.23$ \\
Milk extraction rate (kg/min) & $* *$ & $0.43 \pm 0.04$ & $0.99 \pm 0.07$ \\
Fat $\%$ (\%) & $\mathrm{NS}$ & $4.32 \pm 0.05$ & $4.65 \pm 0.03$ \\
SNF $(\%)$ & $\mathrm{NS}$ & $8.69 \pm 0.05$ & $8.53 \pm 0.03$ \\
\hline
\end{tabular}

**Significant at $1 \%$ level; NS, Non-significant.

slough off from the lining of the mammary gland during normal course of milking (Harmon 1994). They are widely used as marker to determine the mammary health or IMI and quality of milk (Dohoo and Meek 1982, Eberhart et al. 1982). In the present study, higher SCC in hand milk sample could be due to higher chance of injury to quarters (unwilling) during manual operation as compared to mechanized operation and udder faces more exposure to milker or operator during hand milking, who can also act as a source of infection. However, differences in the values of fat and SNF were non-significant among different milking management. Contrary to this, Hamann (2002) reported a decrease in SNF in milk content in very high SCC herds (> 4.0 lakhs).

It may be noted that both (hand and machine) milking management practices were followed in the ERS-NDRI herd. Before every milking, all cows were washed by clean water. Their udders were thoroughly cleaned and teats wiped with towel. The milkers also washed their hands before milking. The dipping of teats in iodine solution after each milking was practiced in the farm. Milk was finally pooled in the bulk tank for transportation.

Hand milking management practices: The analysis of data of hand milking practice (farm experimentation) on IMI and milk characteristics during morning, evening milking session reveals that $\log _{10} \mathrm{SCC}$ (cells $/ \mathrm{ml}$ ) was higher in evening session as compared to morning session (Table $2)$. The SCC $\times 10^{5}$ (cells $\left./ \mathrm{ml}\right)$ greatly varied in both sessions. The MCMT varied non-significantly between two milking sessions with higher value during evening as compared to morning session. The $\mathrm{pH}$ of milk samples from morning and evening milking sessions varied non-significantly with slightly higher $\mathrm{pH}$ during evening time as compared to morning. Although pHs varied in normal range in all milk samples. The milk yield (kg/animal/milking) was significantly $(\mathrm{P}<0.01)$ higher in morning milking session as compared to evening. The time required for milking (minute/animal/milking) was found to be lower during evening as compared to morning time. The milk extraction rate $(\mathrm{kg} /$ minute $)$ was significantly $(\mathrm{P}<0.05)$ higher during morning session as compared to evening session milking. The fat $(\%)$ was slightly higher during morning time as compared to evening session with a non-significant variation. The SNF (\%) varied non-significantly between two sessions with slightly higher value during morning milking time.

Table 2. Incidence of IMI and milk characteristics during different session of hand milking practices

\begin{tabular}{lccc}
\hline Parameter & \multirow{2}{*}{ Sig } & \multicolumn{2}{c}{ Hand milking } \\
\cline { 3 - 4 } & & Morning & Evening \\
\hline $\log _{10}$ SCC $($ cells/ml) & NS & $5.86 \pm 0.08$ & $6.18 \pm 0.05$ \\
SCC $10^{5}(\mathrm{cells} / \mathrm{ml})$ & & $5.98 \pm 0.40$ & $9.47 \pm 0.41$ \\
Range of Log SCC (cells/ml) & & 4.60 to 6.81 & 4.71 to6.92 \\
MCMT & $\mathrm{NS}$ & $2.65 \pm 0.15$ & $3.65 \pm 0.09$ \\
$\mathrm{pH}$ & $\mathrm{NS}$ & $6.63 \pm 0.03$ & $6.68 \pm 0.05$ \\
Milk yield (kg/animal/milking) & $* *$ & $5.45 \pm 0.31$ & $3.31 \pm 0.25$ \\
Time/animal/milking (min) & $\mathrm{NS}$ & $10.48 \pm 0.37$ & $9.66 \pm 0.48$ \\
Milk extraction rate (kg/min) & $*$ & $0.52 \pm 0.04$ & $0.34 \pm 0.05$ \\
Fat $(\%)$ & $\mathrm{NS}$ & $4.42 \pm 0.04$ & $4.41 \pm 0.03$ \\
SNF $(\%)$ & $\mathrm{NS}$ & $8.76 \pm 0.03$ & $8.62 \pm 0.02$ \\
\hline
\end{tabular}

*Significant at $5 \%$ level; **Significant at $1 \%$ level; NS, Non-significant. 
Hamann (2002) termed the word "Gold Standard" for a somatic cell count of up to 100,000 cells $/ \mathrm{ml}$ and values of milk above 100,000 cells $/ \mathrm{ml}$ results in reduction in the milk production and processing properties of milk. In the present study, higher SCC in hand milk sample might be due the constant exposure of animals to the pathogens, which help the easy entry of organism through streak canal responsible for higher rate of infection in hand milked animals in comparison to machine milked animals. Infact streak canal of the teats consists keratinized layer and accumulated cellular debris, which is wax like and have sebum like nature consisting of long chain fatty acids and provides bacteriostatic effects. The breakdown of such streak canal barrier with manual error of hand milking leads to increased frequency of infection with successive increase in lactation number. The changes occur in milk composition and milk yield due to IMI/mastitis and increased SCC level in cow milk in cold dry climate was reported by some workers (Kumaresan 2013), Ballou et al. 1995, Malek dos Reis et al. 2013).

Machine milking management practices: The analysis of data of machine milking practice (farm experimentation) on IMI and milk characteristics during morning, evening milking session reveals that $\log _{10} \mathrm{SCC}$ (cells/ml) was higher in evening session as compared to morning session (Table 3 ). The range of $\mathrm{Log} \mathrm{SCC}$ (cells/ml) greatly varied in both sessions. The MCMT varied non-significantly between two milking sessions with higher value during evening as compared to morning session. The $\mathrm{pH}$ of milk samples from morning and evening milking sessions varied nonsignificantly with slightly higher $\mathrm{pH}$ during evening time as compared to morning. Although $\mathrm{pHs}$ varied in normal range in all milk samples. The milk yield (kg/animal/ milking) was significantly $(\mathrm{P}<0.01)$ higher in morning milking session as compared to evening. The time required for milking (minute/animal/milking) was significantly $(\mathrm{P}<0.05)$ lower during evening as compared to morning time. The milk extraction rate (kg/minute) was higher during morning session as compared to evening session milking.

Table 3. Incidence of IMI and milk characteristics during different session of machine milking practices

\begin{tabular}{lccc}
\hline \multirow{2}{*}{ Parameter } & Sig & \multicolumn{2}{c}{ Machine milking } \\
\cline { 3 - 4 } & & Morning & Evening \\
\hline $\log _{10} \mathrm{SCC}($ cells/ml) & NS & $4.82 \pm 0.06$ & $4.92 \pm 0.05$ \\
$\mathrm{SCC} \times 10^{5}(\mathrm{cells} / \mathrm{ml})$ & & $1.61 \pm 0.29$ & $1.75 \pm 0.31$ \\
Range of Log SCC (cells/ml) & & 3.23 to 5.18 & 3.95 to 5.87 \\
MCMT & $\mathrm{NS}$ & $1.33 \pm 0.09$ & $1.37 \pm 0.08$ \\
$\mathrm{pH}$ & $\mathrm{NS}$ & $6.31 \pm 0.02$ & $6.93 \pm 0.04$ \\
Milk yield (kg/animal/milking) & $* *$ & $6.95 \pm 0.30$ & $4.25 \pm 0.31$ \\
Time/animal/milking (min) & $*$ & $6.19 \pm 0.29$ & $5.10 \pm 0.33$ \\
Milk extraction rate (kg/min) & $\mathrm{NS}$ & $1.12 \pm 0.09$ & $0.83 \pm 0.08$ \\
Fat $(\%)$ & $\mathrm{NS}$ & $4.64 \pm 0.04$ & $4.65 \pm 0.03$ \\
SNF $(\%)$ & $\mathrm{NS}$ & $8.70 \pm 0.05$ & $8.35 \pm 0.04$ \\
\hline
\end{tabular}

*Significant at $5 \%$ level $; * *$ Significant at $1 \%$ level; NS, Nonsignificant.
The fat (\%) was slightly higher during evening time as compared to morning session with a non-significant variation. The SNF (\%) varied non-significantly between two sessions with slightly higher value during morning milking time as compared to evening milking session. Bharti et al. (2015) reported that a significant $(\mathrm{P}<0.01)$ negative correlation of $\log _{10}$ SCC with test day milk yield, fat and SNF percentage.

Milk from healthy mammary gland has about $10^{5}$ somatic cells/ml and values higher than this indicates secretary disturbances (Dang and Singh 2006). In the present study, it was observed that in machine milking systems, human interference was also comparatively less than hand milking which may be the reason for less milk SCC under these systems. Another important reason was proper cleaning of machine and it's parts. Everyday milking machines were cleaned by water immediately after each milking. Daily machines were cleaned by using hot water along with BASIX (soapinifing agents) of DeLaval company. Once in a week, machines were clean by using an acid i.e NOVACID of De-Laval. The teat sphincter and leukocytes (somatic cell) provide defence line for external bacterial attacks which ultimately invaded by pathogenic organisms resulting in increased level of SCC in milk. Under unhygienic conditions, during hand milking as compared to machine milking or due to damaged teat canal, pathological bacteria invade internal mammary tissues and obliterate mammary cell lines.

Scenario at dairy farmer's house at lower Gangetic region: The compilation and analysis of data, observations, information on IMI status and milk composition of animals at farmer's house at lower Gangetic area revealed that SCC greatly varied between IMI animals and non-IMI animals (Table 4). The MCMT and $\mathrm{pH}$ were found to be higher in IMI animals as compared to non-IMI animals. But the fat and SNF (\%) were lower in IMI animals as compared to non-IMI animals.

The IMI lead to changes in glandular tissue of the udder (Sharma 2007). So it is essential to monitor IMI in dairy cows in order to maintain milk quality and udder health. In these villages, calves were allowed to suckle first few drops of milk. If there was no calf under the cow, the milk was added to the milking bucket. Milk of all the animals managed by a farmer was being collected in a single stainless steel or aluminum bucket irrespective of the health condition of animal. The above practices under the village conditions were found to be in total disagreement to our advices regarding clean milk production which advocated the discard of fore milk due to high microbial counts (Dang et al. 2004). Also, for clean milk production, sick or treated animals should be milked at last and their milk should not be collected in vessels with the milk of normal animals.

For the sake of better understanding of implications of management practices at farmer's house, data were classified in three categories viz. farmer having single cow, farmer having 2-3 cows and farmer having more than 3 cows. The management practices (\%) and hygiene status, 
Table 4. The IMI status and milk composition of animals at farmer's house at lower Gangetic area

\begin{tabular}{lcc}
\hline \multirow{2}{*}{ Parameter } & \multicolumn{2}{c}{ Milk samples/animal } \\
\cline { 2 - 3 } & \multicolumn{1}{c}{ IMI } & Non-IMI \\
\hline $\log _{10}$ SCC $($ cells/ml) & $6.55 \pm 0.05$ & $4.05 \pm 0.04$ \\
SCC $\times 10^{5}($ cells/ml) & $30.91 \pm 3.85$ & $1.19 \pm 0.98$ \\
Range of Log SCC (cells/ml) & 5.11 to 7.38 & 3.86 to 5.08 \\
MCMT & $3.56 \pm 0.07$ & $1.41 \pm 0.15$ \\
pH & $6.93 \pm 0.02$ & $6.48 \pm 0.03$ \\
Fat $(\%)$ & $3.90 \pm 0.07$ & $3.95 \pm 0.15$ \\
SNF $(\%)$ & $8.40 \pm 0.06$ & $8.63 \pm 0.08$ \\
\hline
\end{tabular}

Table 5. Management practices (\%) and hygiene status, cleanliness in different animal keeping pattern at farmer's house at lower Gangetic area

\begin{tabular}{lccc}
\hline $\begin{array}{l}\text { Management practices } \\
\text { followed at farmer's house }\end{array}$ & \multicolumn{3}{c}{ Animal keeping pattern } \\
\cline { 2 - 4 } & 1 cow & $\begin{array}{c}2-3 \\
\text { cows }\end{array}$ & $\begin{array}{c}>3 \\
\text { cows }\end{array}$ \\
\hline $\begin{array}{l}\text { Washing of hands } \\
\text { before milking }\end{array}$ & 30 & 32 & 25 \\
$\begin{array}{l}\text { Animal washing } \\
\text { before milking }\end{array}$ & 11 & 4 & 0 \\
$\begin{array}{l}\text { Washing of udder and } \\
\quad \text { teats before milking }\end{array}$ & 19 & 12 & 3 \\
$\begin{array}{l}\text { Washing of collecting } \\
\quad \text { vessel before milking }\end{array}$ & 90 & 94 & 92 \\
$\begin{array}{l}\text { Washing of udder after milking } \\
\text { Teat dipping }\end{array}$ & 2 & 0 & 0 \\
\begin{tabular}{l} 
Screening of udders for mastitis \\
\hline
\end{tabular} & 0 & 0 & 0 \\
\hline
\end{tabular}

cleanliness in different animal keeping pattern indicated that the washing of animal before milking and the washing of udder and teats before milking were higher in single animal case and it reduced with increasing animal number (Table 5). The practice of washing hands before each milking varied between $25 \%$ to $32 \%$. The practice of washing of udder after milking was very little in single animal case and it was not found when animal number was increased. The management practice like teat dipping and screening of udder for mastitis were never found in any cases at any farmer's house.

In lower Gangetic region, the reasons for not following procedures like regular screening of udders or teat dipping post milking were due to low awareness levels and economic reasons. It was also noticed that most of the farmers washed the udders of their lactating cows only in newly calved cows and that too for the first $2-3$ days after parturition. Regular screening of udders was not being practiced under village conditions. The reasons for not following post milking udder washing were mainly related to awareness levels. It may be an important factor in influencing udder health and IMI. Neijenhuis et al. (2001) observed that teat wall and cistern recovered only after 6 and $3 \mathrm{~h}$ of milking: whereas, complete recovery of the teats took more than $9 \mathrm{~h}$. In a later study, the group also reported
Table 6. Association between animal keeping pattern and hygiene status, cleanliness in animals, shedand milkers at farmer's house at lower Gangetic area

\begin{tabular}{lcccc}
\hline \multirow{2}{*}{$\begin{array}{l}\text { Animal number } \\
\text { at farmer's } \\
\text { house }\end{array}$} & \multicolumn{4}{c}{$\begin{array}{l}\text { Hygiene status, cleanliness (animals, } \\
\text { shed, milker) at farmers (\%) household }\end{array}$} \\
\cline { 2 - 5 } & Good & Medium & Poor & Overall \\
\hline 1 Cow & 78.57 & 14.29 & 7.14 & 45.17 \\
2- 3 Cows & 27.27 & 54.55 & 18.18 & 35.48 \\
> Cows & 16.67 & 33.33 & 50.00 & 19.35 \\
Overall & 48.39 & 32.26 & 19.35 & \\
Chi-Square & $12.02 *$ & & & \\
\hline
\end{tabular}

*- Significant at $5 \%$ level.

that post-milking teat dipping reduced the somatic cell counts of milk (Neijenhuis 2003). Bhakat et al. (2016b) found that in this area almost all the cows were Jersey crossbred. All the lactating cows were fed with additional concentrate according to their milk yield. Almost all dairy farmers carried out their daily milking by hand and generally it was done by a professional milker (Gowala).

In our present study, the hygiene status, cleanliness was assessed meticulously in three stages viz. in milking cows itself, at housing of animal and in milkers who were using their hand for milking everyday at farmer's house. The association between animal keeping pattern and hygiene status, cleanliness in animals, shed and milkers at farmer's house revealed that farmer having single cow, maintained good hygiene status, cleanliness but most of the farmer having $>3$ cows, maintained poor hygiene status, cleanliness whereas most of the farmer having 2-3 cows maintained medium type hygiene status, cleanliness in their milking cows, housing of animal and milkers who were using their hand for milking everyday at farmer's house (Table 6). Chisquare test was applied and value was found to be significant $(\mathrm{P}<0.05)$. It was found that the milking places were having not proper drainage and disposal system for both dung and urine; and mostly the floor were of mud type and there was lack of drainage system.

Major concern in lower Gangetic region is that even the minimal values of milk SCC are on the higher side indicating that mammary gland is under stress in these conditions. It has been seen that higher SCC due to poor management practices is very critical because more influx of milk SCC not only disrupts the mammary epithelium but also decreases milk quality (Singh and Dang 2002) which in turn leads to lower returns. Several of these issues can be addressed if we are able to link milk quality with payment. In a previous study also, Bailey and Heald (2000) reported that each load of milk picked up at the farm was tested for SCC and premiums or deductions were made on the milk prices based on the SCC quality. Similarly, Hamann (2002) also emphasized the need to combine payment of milk for quality not only with SCC but also with the changes in milk composition. So far there is no such practice being followed in lower Gangetic region, where farmers are paid for their milk according to the fat percentage of milk. The 
positive advancement of milk intake by consumers should be encouraged by the high quality of raw milk in dairy practice (Tancin 2013). As consumers are becoming more health conscious and general awareness to produce clean milk is increasing, there is a need to educate dairy farmers to follow clean milk production and better management practices, so that they get a good price for their milk and it matches international quality.

Farm experimentation can be concluded that IMI can be reduced in machine milking practices in comparison to hand milking practices with higher milk production without affecting milk quality in Jersey crossbred cows. Field investigation concluded that there is a significant association between animal keeping pattern and hygiene status/ cleanliness at study area. So efforts should be made to increase cleanliness and hygiene status in milking cows itself, housing of animal and milkers of farmer's house to reduce incidence of IMI and to improve clean milk production in changing scenario.

\section{ACKNOWLEDGEMENT}

The authors are highly thankful to the ICAR-NDRI for funding and equally indebted to all dairy farmers who cooperated during data collection and helped directly/ indirectly.

\section{REFERENCES}

Bailey K and Heald C W. 2000. Milk Components and Quality: New Methods for Paying Pennsylvania Dairy Farmers. Penn State College of Agricultural Sciences, Agricultural Research and Cooperative Extension. http://pubs.cas.psu.edu/FreePubs/ $p d f s / u a$ 342.pdf.

Ballou L U, Pasquini M, Bremel R D, Everson T and Dean S R D. 1995. Factors affecting herd milk composition and milk plasmin at four levels of somatic cell counts. Journal of Dairy Science 78: 2186-95.

Bharti P, Bhakat C, Ghosh M K, Dutta T K and Das R. 2015. Relationship among intramammary infection and raw milk parameters in Jersey crossbred cows under hot-humid climate. Journal of Animal Research 5(2): 317 - 20.

Bhaskaran K and Praveena C. 1982. Adoption of improved dry land agricultural technology in an integrated dry land agricultural development project in AP. Indian Journal of Extension Education 18: 32-39.

Bhakat C, Wathore S B, Chatterjee A, Garai S, Karunakaran M, Mandal D K, Rai S, Mandal A and Dutta T K. 2016a. Studies on milking hygiene management and udder health status of dairy cows at Nadia district of WB. Compendium of $44^{\text {th }}$ Dairy Industry Conference at ICAR-NDRI, Feb 18-20,2016, pp 134135.

Bhakat C, Mandal D K, Chatterjee A, Karunakaran M, Asif M, Rai $S$ and Mandal A. 2016b. Influence of clean milk production on incidence of sub-clinical mastitis in cows at lower gangetic regions. Journal of Agriculture Engineering and Food Technology 3(3): 248-52.

Dang A K and Anand S K. 2007. Effect of milking systems on the milk somatic cell counts and composition. Livestock Research for Rural Development 19(6): 1-9.

Dang A K, Anand S K and Singh M. 2004. Mastitis and strategies for its control. Indian Dairyman 56(1): 27-32.

Dang A K and Singh M. 2006. Udder the most important asset of Dairy industry, its care and management. Indian Dairyman 58(8): 57-63.

Devi B K, Shukla P C and Bagherwal R K. 1997. Incidence of sub-clinical mastitis in cows. Indian Journal of Dairy Science 50(6): 477-78.

Dohoo I R and Meek A H. 1982. Somatic cell counts in bovine milk. Canadian Veterinary Journal 23: 119-25.

Eberhart R J, Hutchinson L J and Spencer S B. 1982. Relationship of bulk milk tank somatic cell counts to prevelance of intramammary infection and to indices of herd production. Journal of Food Protection 45: 1125-28.

Hamann J. 2002. Relationships between somatic cell counts and milk composition. Bulletin of the IDF 372: 56-59.

Hanan M, El-Hewairy, Sahar A, Galal, Hamouda R H and Dohreig R M A. 2015. Immunological and bacteriological findings associated with subclinical mastitis in dairy farm. Life Science Journal 12: 139-46.

Harmon R J. 1994. Physiology of mastitis and factors affecting somatic cell count. Journal of Dairy Science 77: 2103-20.

Kumaresan G. 2013. Somatic cell pattern and composition of milk of Holstein Friesian crossbred cattle. International Journal of Enironmental Science Technology 2(6): 1421 - 25.

Malek dos Reis C B, Barreiro J R, Mestieri L, Porcionato M A and dos Santos M V. 2013. Effect of somatic cell count and mastitis pathogens on milk composition in Gyr cows. BMC Veterinary Research 9: 67.

Neijenhuis F, Barkema H W, Hogeveen H and Noordhuizen J P T M. 2001. Relationship between teat end callosity and occurrence of clinical mastitis. Journal of Dairy Science 84: 2664-72.

Neijenhuis F. 2003. International collaboration of teat end condition. Bulletin of the IDF 381/2003 pg-21.

Patil M P, Nagvekar A S, Ingole S D, Bharucha S V and Palve V T. 2015. Somatic cell count and alkaline phosphatase activity in milk for evaluation of mastitis in buffalo. Veterinary World 8(3): 363-66.

Schukken Y H, Wilson D J, Welcome F, Garrison-Tinofsky L and Gonzales R N. 2003. Monitoring udder health and milk quality using somatic cell counts. Veterinary Research 34: 579-96.

Singh M and Dang A K. 2002. Somatic cell counts of milk. National Dairy Research Institute, Publication No: 1/2002.

Sharma N. 2007. Alternative approach to control intramammary infection in dairy cows- A Review. Asian Journal of Animal Veterinary Advances 2(2): 50-62.

Snedecor G W and Cochran W G. 1994. Statistical methods. Affiliated East-West press and Iowa State University press, $8^{\text {th }}$ edition.

Srivastava A K and Khetra Y. 2016. World wide scenario of milk processing and emerging trends. Souvenir of $44^{\text {th }}$ Dairy Industry Conference at ICAR-NDRI, Feb 18-20,2016, pp 1-6.

Tancin V. 2013. Somatic cell counts in milk of dairy cows under practical conditions. Slovak Journal of Animal Science 46(1): 31-34. 